\title{
Defluoridation Capability of Jharkhand Raw Bentonite without Transferring Neurotoxin Aluminium by Potash Alum of Nalgonda Technique
}

\author{
Arushi Gupta ${ }^{1}$, Vats Amitabh ${ }^{2}$, Babita Kumari ${ }^{3}$ and Bivekanand Mishra ${ }^{4}$ \\ ${ }^{\text {I}}$ (Bhagwant University, Ajmer, Rajasthan, India) \\ ${ }^{2}$ (D.N.S College, Rajoun, Banka, India) \\ ${ }^{3}$ (Mahila College, Godda, Jharkhand, India) \\ ${ }^{4}$ (T.M. Bhagalpur University, Bhagalpur, Bihar, India)
}

\begin{abstract}
This work is endeavor to explore the defluoridation capability of raw bentonites first time collected from the woods of Jharkhand hills without transferring neurotoxin aluminium to drinking water as compared with potash alum of Nalgonda technique (NEERI, Nagpur) now declared erroneous. These bentonites are found to have $76.67 \%$ of fluoride removal capacity which has been found to be much more than the fluoride removal capacity of raw bentonites reported till now. The kinetic study of defluoridation by Jharkhand bentonites of different particle size (mesh) revealed that as the particle size of Bentoniteis increased the fluoride removal capacity reduces. Samples AB6(Chitra), AB9(Godda), AB12(Godda), AB16(Godda) and AB17(Dumka)were able to reduce the fluoride concentration by 53.3\%, 73.3\%, 66.6\% 56.6\% and $76.3 \%$ respectively when used with mesh size of 300, while the same samples with mesh size of 150 had fluoride removal capacity of $0 \%$, $33.3 \%, 43.3 \%, 43.3 \%, 33.3 \%$ respectively. Samples like AB10 (Sahibganj), AB18 (Dumka), AB19 (Dumka), AB21 (Daltaganj), AB22 (Lohardaga) and AB23 (Dumka) showed fluoride removal capacities from $56.6 \%$ to 76.6\%. Bentonite, due to its three layered alumino silicate structure does not transfer aluminium to drinking water as potash alum of Nalgonda technique.
\end{abstract}

Key words: Nalgonda Potash alum, Drinking water, Raw Bentoniteof Jharkhand, Defluoridationcapacity, Neurotoxin

\section{Introduction}

The world in twenty first century is still facing an ominous problem of water pollution. The problem is aggravated in rural areas also where people cannot afford state of art and costly technologiesfor provisioning safe drinking water. One of the most common pollutants of water is the fluoride ion. Excess of fluoride ions in drinking water reduces longevity of life through various diseases such asdigestive disorders, skin problems, dental/ skeletal fluorosis andlesions of the endocrine glands, thyroid and liver. The presence of fluoride in drinking water, however, within permissible limits of $1-1.5 \mathrm{mgL}^{-1}$ is beneficial for health. As per WHO standards fluoride concentration below $1 \mathrm{mgL}^{-1}$ too is dangerous as it causes dental cavity, hence it is important that, the optimum fluoride concentration is maintained in water. A number of defluoridation techniques like adsorption [1,2], ion exchange [3], precipitation [4], Donnan dialysis [5-8], electrodialysis [9,10], reverse osmosis [11], nanofiltration [12] and ultrafiltration [13] have been reported in past to remove excessive fluoride from water. However these are expensive and have high operating cost [14].

The most common available method of community defluoridationin India isNalgonda Technique which is based on precipitation process and is very efficient and cost effective. The main limitations of this technique are daily requirement of addition of chemicals, large amount of sludge production, least effective with water having high content of total dissolved solids and high hardness. Besides it converts a large portion of ionic fluoride (67-87\%) into insoluble aluminium complex and practically removes only a small portion of fluoride in the form of precipitate (18-33\%). Therefore, this technique is erroneous [15] residual aluminium ranges from 2.01-6.86 ppm was reported in Nalgonda technique [16] which is dangerous to human health as aluminium is a neurotoxin and concentration as low as $0.08 \mathrm{ppm}$ in drinking water has been reported to cause Alzhemer's disease [17] and has strong carcinogenic properties [18-19]. Hence there is a need to find healthier, locally available defluoridation media, which is less expensive and technically feasible at rural community level.

In past, considerable attention has been devoted to the study of different types of low cost materials such as amorphous alumina [20], calcite [21], bleaching earth [22], redmud [1], charfine, lignites, sirmali seeds, kaolinite, Bentonite [23], montmorillonite [24] for adsorption of fluoride from water. Karthikeyan et.al. [25], Y. Ma et. al. [26], Kamble et. al. [27], Thakre et. al. [28], A. Ramdani, S. Taleb [29] have efficiently used Montmorillonite and modified Bentonite for defloridation of water. Reported data on the removal of fluoride using Bentonite shows that the raw Bentonite has fluoride removal capacity of $46 \%$ [30] while activated 
Bentonitehas a higher capacity but it is expensive and toxic. Recent observation of Arushi Gupta [31, 32] shows that Bentonite of Rajmahal hill may be a suitable alternative for methods of removal of fluoride from water, particularly, potash alum used in the well-established Nalgonda method.

The present study deals with investigation on the use of properties and efficiency of raw Bentonite collected from the woods of Jharkhand hills for defluoridation of water. Use of raw Bentonite extracted from natural resources of Jharkhand hills, for fluoride removal, is being reported for the first time. The method is feasible, effective and low cost alternative of potash alum of Nalgonda method which transfers carcinogenic aluminum to supply water from Ganga water treatment by water works in the cities on the south back of Ganga. The method removes only excess of fluoride, without disturbing the micronutrient requirement level of the body. Raw Bentonite from Jharkhand hills has been found to have $76.67 \%$ fluoride removal capacity which is much more than the fluoride removal capacity of raw Bentonite reported till date.

\section{Experimental}

Twenty Three samples of Bentonitewere collected after thorough survey in the woods of hills of Jharkhand under the team leader Dr. Shashi Shekhar Singh (Geology Department, M.S. College, Bhagalpur) along with team members Dr. Vats Amitabh (Rajoun, Banka) and Dr. Babita Kumari (Mahila College, Godda). Thorough study of the samples was undertaken to trace out good quality Bentonite having commercial values and their properties for fluoride removal using analytical techniques such as X-Ray Fluorescence (XRF), Fourier Transform Infrared Spectroscopy (FTIR) and X-Ray Powder Diffraction (PXRD) [33-34]. Seventeen of these samples having high Montmorillonite content were used for the defluoridation experiment without any pretreatment. The Bentonite samples were dried, crushed and sieved to obtain three different particle sizes of 300 mesh, 200 mesh, and 150 mesh.

The procedure for defluoridation experiment was adopted as used by Karthikeyan et. al. [25]. A fluoride stock solution having concentration of $3 \mathrm{mgL}^{-1}$ was prepared. Batch adsorption experiment was carried out by adding $7 \mathrm{~g}$ of Bentonite without any pretreatment to $100 \mathrm{ml}$ of $3 \mathrm{mgL}^{-1}$ fluoride test solution in an electric shaker operating at $80 \mathrm{rpm}$. The $\mathrm{pH}$ of the medium was neutral and the experiment was carried out at room temperature.

The adsorption time was determined by withdrawing the samples at 10, 20, 30, 40, 50 and 60min. $4 \mathrm{~mL}$ of $3 \mathrm{mgL}^{-1}$ fluoride solution containing $7 \mathrm{gm}$ of Bentonite adsorbent was withdrawn at each time interval. They were filtered through Whatman filter paper No. 42 and the filtrate was analyzed for residual fluoride concentration using Alizarin Visual Method. 15 drops of alizarin reagent was added to $4 \mathrm{~mL}$ of filtrate containing residual fluoride and the change in colour of the solution was noted. In this method, when the reagent of Dye Lake containing Zirconyl ions $\mathrm{ZrO}^{2+}$ is mixed with the filtrate containing residual fluoride, it results in dissociation of a portion of the dye lake into a colorless complex anion of $\mathrm{ZrF}_{6}{ }^{2-}$ and the dye. The degree of color modification is proportional to the concentration of fluoride in the filtrate.Fluoride color chart is used to measure the residual fluoride content of water.

The author has used fluoride test kit using BARC technology (OR-F-01) for the defloridation experiment. The data on fluoride removal capabilities of seventeen samples is placed in Table 1. It was observed that for most of the samples equilibrium was obtained after $40 \mathrm{~min}$ and no significant reduction in concentration of fluoride was observed.

\section{Result and Discussion}

Reduction in fluoride concentration $\left(\mathrm{mgL}^{-1}\right)$ vs time (min) for all the samples was plotted and shown in Fig 1. Analysis of fluoride removal capability using Bentonite of different mesh size shows that as the particle size of Bentoniteis increased the surface area decreases, thereby decreasing the number of active sites for fluoride adsorption. Thus the fluoride removal capability of Bentonitereduces. Maximum removal of fluoride was achieved using Bentonite of 300 mesh size whereas the minimum removal was observed when Bentonite of 150 mesh size was used. Samples AB6 (Chitra), AB9, AB12, AB16 (Godda) and AB17 (Dumka) were able to reduce the fluoride concentration by $53.3 \%, 73.3 \%, 66.6 \%, 56.6 \%$ and $76.3 \%$ respectively when used with mesh size of 300 , while the same samples with mesh size of 150 had fluoride removal capacity of $0 \%, 33.3 \%$, $43.3 \%, 43.3 \%$ and $33.3 \%$ respectively. This is attributed to adsorption process being a surface phenomenon. As the particle size is decreased, the surface area of adsorbent increases, thereby increasing the fluoride removal capacity of Bentonite sample.

However samples like AB10 (Sahibganj), AB18, AB19 (Dumka), AB21 (Daltaganj), AB22 (Lohardaga) and AB23 (Dumka) showed same fluoride removal capacities with all three mesh sizes. The percentage removal of fluoride for these samples varied from $56.6 \%$ to $76.6 \%$. The fluoride removal capability is attributed to the presence of large quantityof Montmorillonite and high aluminum in these Bentonite samples $[33,34]$. A high aluminum content present in these samples benefits fluoride sorption as the majority of sorption 
takes place at the aluminum sheets. The adsorption process involves immediate displacement of surface hydroxyl groups.

In Nalagonda Technique aluminiumsulphate is added to water for removal of fluoride. In this process insoluble $\mathrm{Al}(\mathrm{OH})_{3}$ is formed which sediments to the bottom and co-precipitates fluoride along with it. As a result the process removes only a smaller portion of fluoride (18-33\%) in the form of precipitate and removes a larger portion of fluoride in form of soluble $\mathrm{Al}^{3+} \mathrm{F}^{-}$complex ions which are toxic and still remain in water after treatment creating problem of leaching of Aluminium in water. The presence of residual aluminium which is neurotoxic makes Nalgonda technique a less desirable fluoride removal technique. Even the $\mathrm{SO}_{4}{ }^{2-}$ ion concentration from $\mathrm{Al}_{2}\left(\mathrm{SO}_{4}\right)_{3}$ increases and crosses the permissible limit.

However, in the proposed technique where the Bentonite is used for removal of fluoride, fluoride removal occurs by sorption in aluminosilicate through ion exchange between fluoride and hydroxyl group from clay lattice. Due to coordinative binding between fluoride ions and aluminium ions in the octahederal layer the surface hydroxyl groups are displaced. Fluoride has same ionic radius as hydroxyl ion, thus forming a very stable complex with Aluminium $\left(\mathrm{AlF}_{6}\right)^{3-}$ in the octahederal layer. Although ion exchange is the main mechanism for fluoride removal by alumino silicates, $\mathrm{F}^{-}$ion is also immobilized through formation of complexes or precipitate with clay exchangeable cations like $\mathrm{Mg}^{2+}, \mathrm{Fe}^{3+}$ etc or it gets attracted to the clay electrostatically and retained in the electric double layer [35].This makes usage of Bentonite a better fluoride removal technique than Nalgonda process.

Few Bentonitesamples AB5 (Deoghar), AB8 (Dumka), AB13 (Daltaganj) and AB20 (Godda) samples have exhibited intermediate capabilities of fluoride removal. These samples have observed to release fluoride when kept for longer duration.Desorption of fluoride hence can be attributed to the presenceof Kaolinitealong with Montmorillonite in these Bentonite samples [36]. In addition to the surface hydroxyl groups, a Kaolinite crystal has one basal surface composed of Al-OH linkages. The more accessible Aluminium ions areevidently dissolved quite readily and co-ordinate six Fluoride ions in solution. The removal of these Aluminium ions at plate edges exposes $\mathrm{OH}$ ions for replacement by fluoride ion. As a result Kaolinite produces approximately three times of the hydroxide ions that are released by Montmorillonite during fluoride adsorption under similar circumstances $^{36}$. The $\mathrm{pH}$ of the solution increases and makes it alkaline. As alkalinity of the solution increases, the repulsion between negatively charged surface site of adsorbent and fluoride increases resulting in desorption. When the concentration of fluoride increases in the solution it again gets adsorbed on the adsorbent. In sample AB5 the fluoride concentration has found to reduce to $2 \mathrm{mgL}^{-1}$ in $5 \mathrm{~min}$ for 150 mesh size. Fluoride desorption was seen to occur at 10 mins. The fluoride again got adsorbed in 20 mins and the trend continued through the reaction.

The adsorption rate constant (k) for adsorption of fluoride by different samples of Bentonite was determined using the following Lagergren first order rate expression

$$
\log \left(\mathrm{q}_{\mathrm{o}} \mathrm{q}\right)=\log \left(\mathrm{q}_{\mathrm{e}}\right)-(\mathrm{k} / 2.303) \mathrm{X} \mathrm{t}
$$

where, $q_{o}$ is the initial concentration of fluoride, $q$ is the present concentration and $q_{e}$ is the total fluoride removed at equilibrium. The graphs for kinetics of these samples plotted between $\log \left(\mathrm{q}_{\mathrm{o}}-\mathrm{q}\right)$ and $\mathrm{t}$ are shown in Fig 2-4. The rate of reaction was observed to be maximum in first $10 \mathrm{~min}$ and it gradually reduced and reached equilibrium in $40 \mathrm{~min}$. The value of $\mathrm{k}$ for different samples was calculated from the graphs and is provided at Table 2.

The adsorption rate constant $\mathrm{k}$ for initial fluoride concentration of $3 \mathrm{mg} / \mathrm{L}$ for 300 mesh size Bentonite samples varied from $3.34 \times 10^{-3} \mathrm{~min}^{-1}$ (AB20) to $-7.83 \times 10^{-3} \mathrm{~min}^{-1}$ (AB23). The value of $\mathrm{k}$ for 200mesh size Bentonite samples were between $2.08 \times 10^{-2} \mathrm{~min}^{-1}$ (AB11) to $-3.78 \times 10^{-3} \mathrm{~min}^{-1}$ (AB22). For the samples of 150 mesh the range was $6.87 \times 10^{-3} \mathrm{~min}^{-1}$ (AB16) to $-6.7 \times 10^{-3} \mathrm{~min}^{-1}$ (AB6).

The slope of the straight line equation gives the adsorption rate constant $(\mathrm{k})$ and the intercept provides the amount of fluoride removed in first 10 minutes of the reaction. The negative values of adsorption rate constant (k) indicate occurrence of desorption along with adsorption of fluoride in the sample whereas positive values indicate adsorption throughout the experiment. The magnitude of $\mathrm{k}$ value indicates the extent of adsorption or desorption.

\section{Conclusion}

It has been observed that raw Bentonite from Jharkhand hills is able to reduce the concentration of fluoride from $3 \mathrm{mgL}^{-1}$ to acceptable level of $1-1.5 \mathrm{mgL}^{-1}$. The work presented in the paper proves that raw Bentonite of Jharkhand hills has fluoride removal capacity which is comparable to that of activated Bentonite which has been reported in past. The proposed method does not require any pretreatment/ modification to Bentonite and hence is highly cost effective. The proposed method not only brings the fluoride levels in acceptable limits but also overcomes the problems posed by Nalgaonda technique. Hence the Bentonite of Jharkhand hills is a very strong contender for solving the problem of rural population of Jharkhand by giving them an optimum and safe method for obtaining portable water. 


\section{References}

[1] Y. Cengeloglu, E. Kir, M. Ersoz, Sep. Purif. Technol.,81-86 (2002).

[2] A. Tor, Desalination, 201, 2006, 267-276.

[3] S. Meenakshi, N. Viswanathan, J. Colloid Interface Sci., 308, 2007, 438-450.

[4] M.G. Sujana, R.S. Thakur, S.N. Das, S.B. Rao, Asian J. Chem., 4, 1997, 561-570.

[5] F. Durmaz, H. Kara, Y. Cengeloglu, M. Ersoz, Desalination, 177, 2005, 51-57.

[6] A. Tor, J. Hazard. Mater., 141, 2006, 814-818.

[7] E. Kir, E. Alkan, Desalination, 197, 2006, 217-224.

[8] M. Hichour, F. Persin, J. Sandeaux, C. Gavach, Sep. Purif. Technol., 18, 2000, 1-11.

[9] M. Zeni, R. Riveros, K. Melo, R. Primieri, S. Lorenzini, Desalination, 185, 2005, 241-244.

[10] N. Kabay, O. Arar, S. Samatya, U. Yuksel, M. Yuksel, J. Hazard. Mater., 153, 2008, 107-113.

[11] S. Sourirajan, T. Matsurra, Water Res., 6, 1972, 1073-1086.

[12] R. Simons, Desalination, 89, 1993, 325-341.

[13] L. Guo, B.J. Hunt, P.H. Santsci, Water Res., 35 (6), 2001, 1500-1508.

[14] R. Gong, Y. Ding, M. Li, C. Yang, H. Liu, Y. Sun, Dyes Pigments, 64, 2005, 187-192.

[15] B.V. Apparao, S. Meenakshi and G. Karthikayan, Indian J. Environ. Protect., 10, 1990, 292.

[16] S.K. Gupta, Indian J. Environ. Sci., 1, 1997, 149.

[17] A.M. Davison, TheLancent, 9, 1982, 785.

[18] D.R. Crapper, S.S. Krishnan and A.J. Dalton, Science, 180, 1973, 511

[19] K.L. Dearfield, C.O. Abemathy, S. Ottley, J.H. Brantner and P.F. Hayes, Mutation Res., 195, 1964, 45.

[20] P.Nayak, Environ. Res. Sec. A, 89, 2002, 101-115.

[21] Y.H. Li, S.Wang, A. Cao, D. Zhao, X. Zhang, C. Xu, Z. Luan, D. Ruan, J. Liang, D.Wu,B.Wei, Chem. Phys. Lett., 350, 2001, 412416.

[22] M. Yang, T. Hashimoto, N. Hoshi, H. Myoga, Water Res., 33, 1999, 3395-3402.

[23] M. Mahramanlioglu, I. Kizilcikli, I.O. Bicer, J. Flourine Chem., 115, 2002, 41-47.

[24] M. Srimurali, A. Pragathi, J. Karthikeyan, Environ. Pollut., 99, 1998, 285-289.

[25] G. Karthikeyan, AnithaPius, Alagumuthu, Indian Journal of Chemical Technology, 12,2005, $263-272$.

[26] Y. Ma, F. Shi, X. Zheng, J. Ma, C.Gao, Journal of Hazardous Materials, 185, 2011, 1073-1080.

[27] S. P. Kamble, P.Dixit,S. S. Rayalu, N. K. Labhsetwar, Desalination, 249, 2009, 687-693.

[28] D.Thakre, S.Rayalu, R.Kawade, S.Meshram, J. Subrt, N.Labhsetwar, Journal of Hazardous Materials, 180, $2010,122-130$.

[29] A. Ramdani, S. Taleb, A. Benghalem, N. Ghaffour, Desalination, 250,2010, 408-413.

[30] M. Srimurali, A. Pragathi, J. Karthikeyan, Environ. Pollut., 99, 1998, 285-289.

[31] A. Gupta, M. Kumar, A.K. Jha, B.K. Mishra, J. Choudhary and B. Mishra, Asian Journal of Chemistry, 23(12), 2011, 5491-5494.

[32] A. Gupta, M. Kumar, J. Choudhary and B. Mishra, Communicated to Journal of Indian Chemical Society(2013).

[33] A. Gupta, V.Amitabh, B.Kumari, B. Mishra, IOSR Journal of Analytical Chemistry,4 (4), 2013, 42-46.

[34] A. Gupta, V.Amitabh ,B.Kumari, B. Mishra, Research Journal of Pharmaceutical, Biological and Chemical Sciences, 4(3), 2013, 360-369.

[35] Samson, H.R., Clay Miner. Bull., 1, 1952, 266.

[36] P.M.H. Kau, D.W. Smith, P. Binning, Geoderma, 84, 1998, 89-108.

Table - 1. Fluoride removal Capacity of Jharkhand Bentonite

\begin{tabular}{|c|c|c|c|c|c|c|c|c|c|c|c|c|c|c|c|c|c|}
\hline \multicolumn{18}{|c|}{300 mesh } \\
\hline $\begin{array}{c}\mathrm{Ti} \\
\mathrm{me} \\
(\mathrm{mi} \\
\mathrm{n})\end{array}$ & $\begin{array}{c}\mathbf{A B} \\
\mathbf{5}(\mathrm{D} \\
\text { eog } \\
\text { har) } \\
\mathrm{mg} / \\
\mathrm{L}\end{array}$ & $\begin{array}{l}\mathbf{A B} \\
\mathbf{6}(\mathrm{C} \\
\text { hitr } \\
\text { a)m } \\
\text { g/L }\end{array}$ & $\begin{array}{c}\text { AB } \\
7(\mathrm{Ja} \\
\text { sidi } \\
\text { h) } \\
\mathrm{mg} / \\
\mathrm{L}\end{array}$ & $\begin{array}{c}\mathbf{A B} \\
\mathbf{8}(\mathrm{Du} \\
\mathrm{mka}) \\
\mathrm{mg} / \\
\mathrm{L}\end{array}$ & $\begin{array}{c}\text { AB } \\
9(G \\
\text { odd } \\
\text { a) } \\
\text { mg/ } \\
\text { L }\end{array}$ & $\begin{array}{c}\mathbf{A B} \\
\mathbf{1 0}( \\
\text { Sah } \\
\text { ibg } \\
\text { anj) } \\
\mathrm{mg} / \\
\mathrm{L} \\
\end{array}$ & $\begin{array}{c}\mathbf{A B} \\
\mathbf{1 1}( \\
\text { Sah } \\
\text { ibg } \\
\text { anj) } \\
\mathrm{mg} / \\
\text { L }\end{array}$ & $\begin{array}{c}\mathbf{A B} \\
\mathbf{1 2}( \\
\text { God } \\
\mathrm{da}) \\
\mathrm{mg} / \\
\mathrm{L}\end{array}$ & $\begin{array}{c}\text { AB1 } \\
\text { 3(Da } \\
\text { ltaga } \\
\text { nj) } \\
\text { mg/ } \\
\text { L }\end{array}$ & $\begin{array}{c}\mathbf{A B} \\
\mathbf{1 6}( \\
\text { Go } \\
\text { dda } \\
\text { ) } \\
\mathrm{mg} / \\
\mathrm{L} \\
\end{array}$ & $\begin{array}{c}\mathbf{A B} \\
\mathbf{1 7}( \\
\mathrm{Du} \\
\mathrm{mk} \\
\mathrm{a}) \\
\mathrm{mg} / \\
\mathrm{L} \\
\end{array}$ & $\begin{array}{c}\mathbf{A B} \\
\mathbf{1 8}( \\
\mathrm{Du} \\
\mathrm{mk} \\
\mathrm{a}) \\
\mathrm{mg} / \\
\mathrm{L}\end{array}$ & $\begin{array}{c}\mathbf{A B} \\
\mathbf{1 9}( \\
\mathrm{Du} \\
\mathrm{mk} \\
\mathrm{a}) \\
\mathrm{mg} / \\
\mathrm{L}\end{array}$ & $\begin{array}{c}\mathbf{A B} \\
\mathbf{2 0}( \\
\text { Go } \\
\text { dda } \\
\text { ) } \\
\mathrm{mg} / \\
\mathrm{L} \\
\end{array}$ & $\begin{array}{c}\mathbf{A B} \\
\mathbf{2 1}( \\
\mathrm{Dal} \\
\text { taga } \\
\mathrm{nj}) \\
\mathrm{mg} / \\
\mathrm{L}\end{array}$ & $\begin{array}{c}\text { AB2 } \\
\text { 2(Lo } \\
\text { hard } \\
\text { aga) } \\
\text { mg/ } \\
\text { L }\end{array}$ & $\begin{array}{c}\mathbf{A B} \\
\mathbf{2 3}( \\
\mathrm{Du} \\
\mathrm{mka} \\
\text { ) } \\
\mathrm{mg} / \\
\mathrm{L}\end{array}$ \\
\hline 0 & 3 & 3 & 3 & 3 & 3 & 3 & 3 & 3 & 3 & 3 & 3 & 3 & 3 & 3 & 3 & 3 & 3 \\
\hline 5 & 1.5 & 1.4 & 3 & 1.7 & 1.3 & 1.2 & 2.8 & 1.3 & 1.2 & 1.5 & 1.2 & 1.5 & 1.5 & 2.5 & 1.5 & 1.5 & 1.2 \\
\hline 10 & 1.4 & 1.4 & 3 & 2 & 1 & 1 & 2.5 & 1.2 & 1.1 & 1.3 & 1 & 1.4 & 1.3 & 2.3 & 1.6 & 1.4 & 1 \\
\hline 20 & 1.2 & 1.3 & 3 & 1.7 & 0.8 & 0.8 & 2.5 & 1 & 1 & 1.4 & 1.2 & 1 & 1.4 & 2.4 & 1.5 & 1.3 & 0.8 \\
\hline 30 & 1.3 & 1.1 & 3 & 1.8 & 0.7 & 1.1 & 2.5 & 1 & 1.4 & 1.5 & 1.2 & 1.5 & 1.2 & 2.5 & 1.6 & 1.3 & 0.8 \\
\hline 40 & 1.3 & 1.4 & 3 & 1.6 & 1 & 1 & 2.5 & 1.2 & 1.3 & 1.4 & 1.1 & 1.4 & 1.3 & 2.5 & 1.5 & 1.3 & 0.7 \\
\hline 50 & 1.3 & 1.6 & 3 & 1.8 & 0.8 & 1 & 2.6 & 1.2 & 1 & 1.4 & 1 & 1.3 & 1.2 & 2.6 & 1.5 & 1.4 & 0.7 \\
\hline 60 & 1.3 & 1.4 & 3 & 1.8 & 0.8 & 1 & 2.5 & 1 & 1.2 & 1.3 & 1 & 1.4 & 1.2 & 2.6 & 1.5 & 1.3 & 0.8 \\
\hline
\end{tabular}




\begin{tabular}{|c|c|c|c|c|c|c|c|c|c|c|c|c|c|c|c|c|c|}
\hline \multicolumn{18}{|c|}{200 mesh } \\
\hline $\begin{array}{c}\text { Ti } \\
\text { me } \\
\text { (mi } \\
\text { n) }\end{array}$ & $\begin{array}{c}\mathbf{A B} \\
\mathbf{5}(\mathrm{D} \\
\text { eog } \\
\text { har }) \\
\mathrm{mg} / \\
\mathrm{L}\end{array}$ & $\begin{array}{l}\mathbf{A B} \\
\mathbf{6}(\mathrm{C} \\
\text { hitr } \\
\text { a)m } \\
\text { g/L }\end{array}$ & $\begin{array}{c}\mathbf{A B} \\
7(\mathrm{Ja} \\
\text { sidi } \\
\mathrm{h}) \\
\mathrm{mg} / \\
\mathrm{L}\end{array}$ & $\begin{array}{c}\text { AB } \\
\text { 8(Du } \\
\text { mka) } \\
\text { mg/ } \\
\text { L }\end{array}$ & $\begin{array}{c}\mathbf{A B} \\
\mathbf{9}(\mathrm{G} \\
\text { odd } \\
\text { a) } \\
\mathrm{mg} / \\
\mathrm{L}\end{array}$ & $\begin{array}{c}\mathbf{A B} \\
\mathbf{1 0}( \\
\text { Sah } \\
\text { ibg } \\
\text { anj) } \\
\mathrm{mg} / \\
\mathrm{L} \\
\end{array}$ & $\begin{array}{c}\mathbf{A B} \\
\mathbf{1 1}( \\
\text { Sah } \\
\text { ibg } \\
\text { anj) } \\
\mathrm{mg} / \\
\text { L }\end{array}$ & $\begin{array}{c}\text { AB } \\
\mathbf{1 2}( \\
\text { God } \\
\text { da) } \\
\text { mg/ } \\
\text { L }\end{array}$ & $\begin{array}{c}\text { AB1 } \\
\text { 3(Da } \\
\text { ltaga } \\
\text { nj) } \\
\text { mg/ } \\
\text { L }\end{array}$ & $\begin{array}{c}\text { AB } \\
\mathbf{1 6}( \\
\text { Go } \\
\text { dda } \\
\text { ) } \\
\text { mg/ } \\
\text { L }\end{array}$ & $\begin{array}{c}\mathbf{A B} \\
\mathbf{1 7}( \\
\mathrm{Du} \\
\mathrm{mk} \\
\mathrm{a}) \\
\mathrm{mg} / \\
\mathrm{L} \\
\end{array}$ & $\begin{array}{c}\mathbf{A B} \\
\mathbf{1 8}( \\
\mathrm{Du} \\
\mathrm{mk} \\
\mathrm{a}) \\
\mathrm{mg} / \\
\mathrm{L} \\
\end{array}$ & $\begin{array}{c}\mathbf{A B} \\
\mathbf{1 9}( \\
\mathrm{Du} \\
\mathrm{mk} \\
\mathrm{a}) \\
\mathrm{mg} / \\
\mathrm{L}\end{array}$ & $\begin{array}{c}\mathbf{A B} \\
\mathbf{2 0}( \\
\mathrm{Go} \\
\mathrm{dda} \\
\text { ) } \\
\mathrm{mg} / \\
\mathrm{L}\end{array}$ & $\begin{array}{c}\mathbf{A B} \\
\mathbf{2 1}( \\
\mathrm{Dal} \\
\text { taga } \\
\mathrm{nj}) \\
\mathrm{mg} / \\
\mathrm{L}\end{array}$ & $\begin{array}{c}\text { AB } \\
\mathbf{2 2 (} \\
\text { Loh } \\
\text { arda } \\
\text { ga) } \\
\mathrm{mg} / \\
\mathrm{L} \\
\end{array}$ & $\begin{array}{c}\text { AB2 } \\
\text { 3(D } \\
\text { umk } \\
\text { a) } \\
\mathrm{mg} / \\
\mathrm{L}\end{array}$ \\
\hline 0 & 3 & 3 & 3 & 3 & 3 & 3 & 3 & 3 & 3 & 3 & 3 & 3 & 3 & 3 & 3 & 3 & 3 \\
\hline 5 & 2 & 1.8 & 3 & 2 & 1.4 & 1.3 & 2.8 & 1.5 & 1.5 & 1.8 & 1 & 1.5 & 1.5 & 2.5 & 1.8 & 1.3 & 1.2 \\
\hline 10 & 2 & 1.5 & 3 & 1.5 & 1.2 & 1.1 & 2.8 & 1 & 1.2 & 2 & 0.7 & 1.2 & 1.3 & 2 & 1.6 & 1.2 & 1 \\
\hline 20 & 2 & 1.5 & 3 & 1.3 & 1 & 1 & 2.8 & 1 & 1.5 & 1.6 & 0.7 & 1.1 & 1.1 & 2 & 1 & 1.1 & 1 \\
\hline 30 & 2 & 1.5 & 3 & 1.3 & 0.8 & 0.8 & 2.5 & 1 & 0.1 & 1.6 & 0.8 & 1.3 & 1.2 & 2 & 1.7 & 1.5 & 1.3 \\
\hline 40 & 2 & 1.3 & 3 & 1.8 & 1 & 0.8 & 2.5 & 1 & 1.2 & 1.6 & 0.7 & 1.4 & 1.3 & 3 & 1.8 & 1.5 & 0.8 \\
\hline 50 & 2 & 1.5 & 3 & 1.5 & 1 & 0.8 & 2.5 & 1 & 1.2 & 1.6 & 0.7 & 1.5 & 1.2 & 2 & 1.7 & 1.5 & 1 \\
\hline 60 & 2 & 1.5 & 3 & 2 & 1 & 0.8 & 2.5 & 1 & 1.2 & 1.6 & 0.7 & 1.5 & 1.2 & 2 & 1.8 & 1.5 & 1 \\
\hline
\end{tabular}

\begin{tabular}{|c|c|c|c|c|c|c|c|c|c|c|c|c|c|c|c|c|}
\hline \multicolumn{17}{|c|}{150 mesh } \\
\hline $\begin{array}{c}\text { Ti } \\
\text { me } \\
(\mathbf{m i} \\
\text { n) }\end{array}$ & $\begin{array}{c}\mathbf{A B} \\
\mathbf{5}(\mathrm{D} \\
\text { eog } \\
\text { har }) \\
\mathrm{mg} / \\
\mathrm{L}\end{array}$ & $\begin{array}{l}\mathbf{A B} \\
\mathbf{6}(\mathrm{C} \\
\text { hitr } \\
\text { a)m } \\
\text { g/L }\end{array}$ & $\begin{array}{c}\mathbf{A B} \\
7(\mathrm{Ja} \\
\text { sidi } \\
\mathrm{h}) \\
\mathrm{mg} / \\
\mathrm{L}\end{array}$ & $\begin{array}{c}\mathbf{A B} \\
\mathbf{8}(\mathrm{Du} \\
\mathrm{mka}) \\
\mathrm{mg} / \\
\mathrm{L}\end{array}$ & $\begin{array}{c}\text { AB } \\
9(\mathrm{G} \\
\text { odd } \\
\text { a) } \\
\mathrm{mg} / \\
\mathrm{L}\end{array}$ & $\begin{array}{c}\text { AB } \\
\mathbf{1 0}( \\
\text { Sah } \\
\text { ibg } \\
\text { anj) } \\
\text { mg/ } \\
\text { L }\end{array}$ & $\begin{array}{c}\text { AB } \\
\mathbf{1 1}( \\
\text { Sah } \\
\text { ibg } \\
\text { anj) } \\
\text { mg/ } \\
\text { L }\end{array}$ & $\begin{array}{c}\text { AB } \\
\mathbf{1 2}( \\
\text { God } \\
\text { da) } \\
\mathrm{mg} / \\
\mathrm{L}\end{array}$ & $\begin{array}{c}\text { AB1 } \\
\text { 3(Da } \\
\text { ltaga } \\
\text { nj) } \\
\mathrm{mg} / \\
\mathrm{L}\end{array}$ & $\begin{array}{c}\mathbf{A B} \\
\mathbf{1 6}( \\
\text { Go } \\
\mathrm{dda} \\
\text { ) } \\
\mathrm{mg} / \\
\mathrm{L}\end{array}$ & $\begin{array}{c}\text { AB } \\
\mathbf{1 7}( \\
\mathrm{Du} \\
\mathrm{mk} \\
\mathrm{a}) \\
\mathrm{mg} / \\
\mathrm{L}\end{array}$ & $\begin{array}{c}\text { AB } \\
\mathbf{1 8}( \\
\mathrm{Du} \\
\mathrm{mk} \\
\mathrm{a}) \\
\mathrm{mg} / \\
\mathrm{L}\end{array}$ & $\begin{array}{c}\mathbf{A B} \\
\mathbf{1 9}( \\
\mathrm{Du} \\
\mathrm{mk} \\
\mathrm{a}) \\
\mathrm{mg} / \\
\mathrm{L}\end{array}$ & $\begin{array}{c}\text { AB } \\
\mathbf{2 1}( \\
\text { Dal } \\
\text { taga } \\
\text { nj) } \\
\mathrm{mg} / \\
\mathrm{L}\end{array}$ & $\begin{array}{c}\text { AB } \\
\mathbf{2 2}( \\
\text { Loh } \\
\text { ard } \\
\text { aga } \\
\text { ) } \\
\mathrm{mg} / \\
\mathrm{L}\end{array}$ & $\begin{array}{c}\mathbf{A B} \\
\mathbf{2 3}( \\
\mathrm{Du} \\
\mathrm{mka} \\
\text { ) } \\
\mathrm{mg} / \\
\mathrm{L}\end{array}$ \\
\hline 0 & 3 & 3 & 3 & 3 & 3 & 3 & 3 & 3 & 3 & 3 & 3 & 3 & 3 & 3 & 3 & 3 \\
\hline 5 & 2 & 3 & 3 & 3 & 1.8 & 1.5 & 3 & 1.8 & 1.8 & 2.5 & 1.6 & 1.3 & 1.3 & 1.5 & 1.3 & 1 \\
\hline 10 & 3 & 2 & 3 & 2.8 & 1.6 & 1.1 & 3 & 1.7 & 1.7 & 2.5 & 1.3 & 1.2 & 1.2 & 1.4 & 1.3 & 1.2 \\
\hline 20 & 1.8 & 2 & 3 & 2.8 & 3 & 1 & 3 & 1.8 & 1.6 & 2.5 & 1 & 1.1 & 1.1 & 1.5 & 1.3 & 1 \\
\hline 30 & 1.5 & 1.8 & 3 & 2.8 & 3 & 1 & 3 & 1.7 & 1.6 & 2.3 & 1 & 1 & 1 & 1.4 & 1.3 & 1 \\
\hline 40 & 2 & 3 & 3 & 2.8 & 1.6 & 1.3 & 3 & 1.7 & 1.6 & 2 & 1 & 1.3 & 1.3 & 1.4 & 1.2 & 0.9 \\
\hline 50 & 3 & 2.8 & 3 & 2.8 & 1.7 & 1 & 2.8 & 1.7 & 1.6 & 2 & 1 & 1.4 & 1.4 & 1.3 & 1.3 & 0.7 \\
\hline 60 & 3 & 2 & 3 & 2.8 & 1.7 & 1 & 2.8 & 1.7 & 1.6 & 2 & 1 & 1.3 & 1.3 & 1.4 & 1.2 & 0.7 \\
\hline
\end{tabular}


Table -2. k value for Kinetics equation for removal of Fluoride

\begin{tabular}{|c|c|c|c|c|c|c|c|c|}
\hline \multicolumn{9}{|c|}{300 mesh samples } \\
\hline Sample & AB5 & AB6 & AB 8 & AB9 & AB10 & AB11 & AB 12 & AB13 \\
\hline $\mathbf{k}\left(\mathrm{MIN}^{-1}\right)$ & $1.53 \times 10^{-03}$ & $-\underset{03}{-1.33 \times 10^{-}}$ & $9.1 \times 10^{-04}$ & $3.04 \times 10^{-03}$ & $6.84 \times 10^{-04}$ & $7.65 \times 10^{-03}$ & $1.33 \times 10^{-03}$ & $-3.0 \times 10^{-04}$ \\
\hline Sample & AB16 & AB17 & AB18 & AB19 & AB20 & AB21 & AB22 & AB23 \\
\hline $\mathbf{k}\left(\min ^{-1}\right)$ & $8.8 \times 10^{-04}$ & $1.36 \times 10^{-03}$ & $1.9 \times 10^{-04}$ & $2.6 \times 10^{-03}$ & $-7.83 \times 10^{-03}$ & $59 \times 10^{-04}$ & $1.31 \times 10^{-03}$ & $3.34 \times 10^{-03}$ \\
\hline \multicolumn{9}{|c|}{200 mesh samples } \\
\hline$k\left(\min ^{-1}\right)$ & 0 & $2.74 \times 10^{-03}$ & -0.0019 & $3.10 \times 10^{-03}$ & $4.24 \times 10^{-03}$ & $2.07 \times 10^{-02}$ & $2.93 \times 10^{-03}$ & $2.5 \times 10^{-03}$ \\
\hline Sample & AB16 & AB17 & AB18 & AB19 & AB20 & AB21 & AB22 & AB23 \\
\hline $\mathbf{k}\left(\min ^{-1}\right)$ & $4.33 \times 10^{-03}$ & $1.44 \times 10^{-03}$ & $-2.3 \times 10^{-03}$ & $1.89 \times 10^{-03}$ & $6.9 \times 10^{-03}$ & $-2.9 \times 10^{-03}$ & $-3.8 \times 10^{-03}$ & $1.47 \times 10^{-03}$ \\
\hline \multicolumn{9}{|c|}{150 mesh samples } \\
\hline Sample & AB5 & AB6 & AB 8 & AB9 & AB10 & AB11 & AB 12 & \\
\hline
\end{tabular}
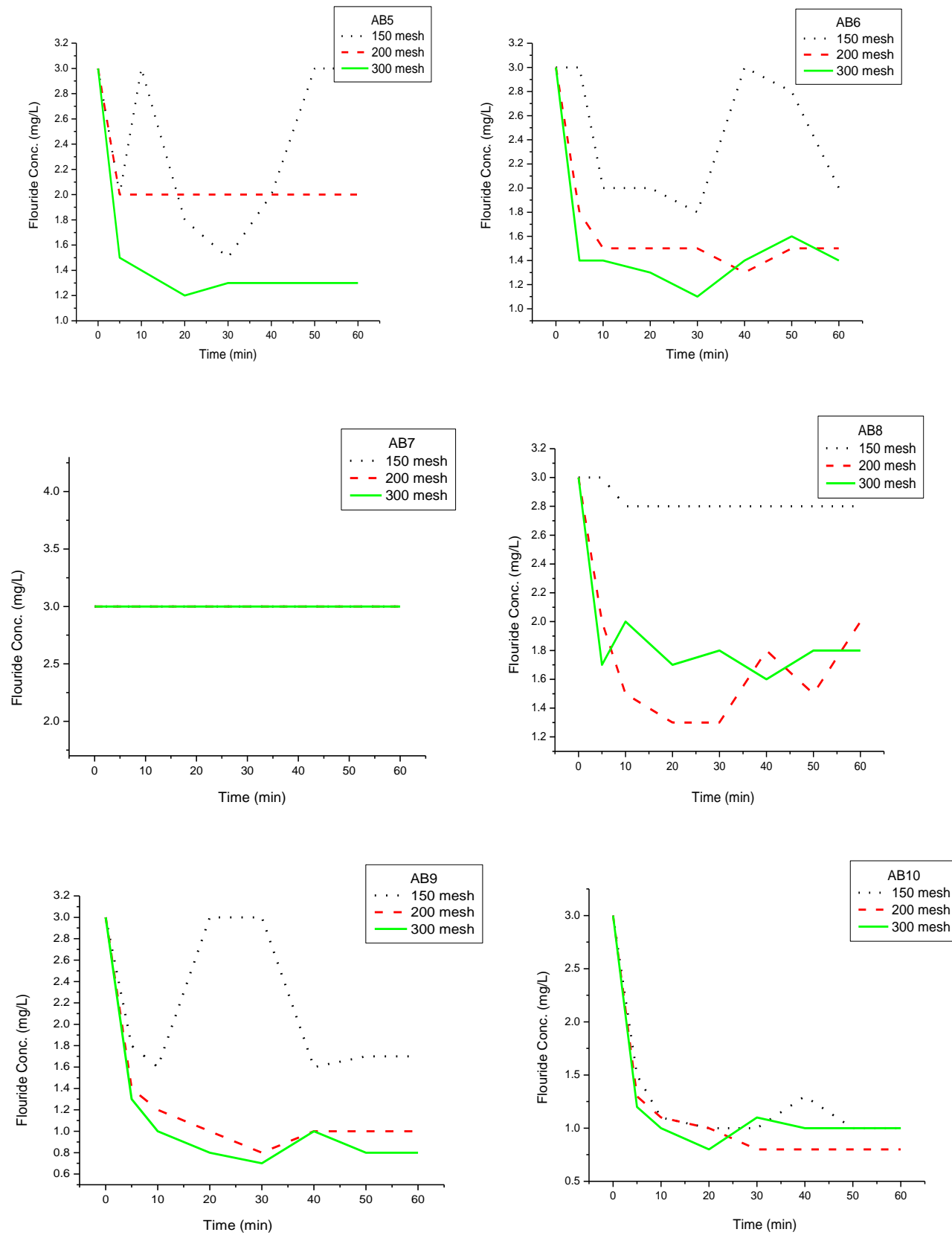

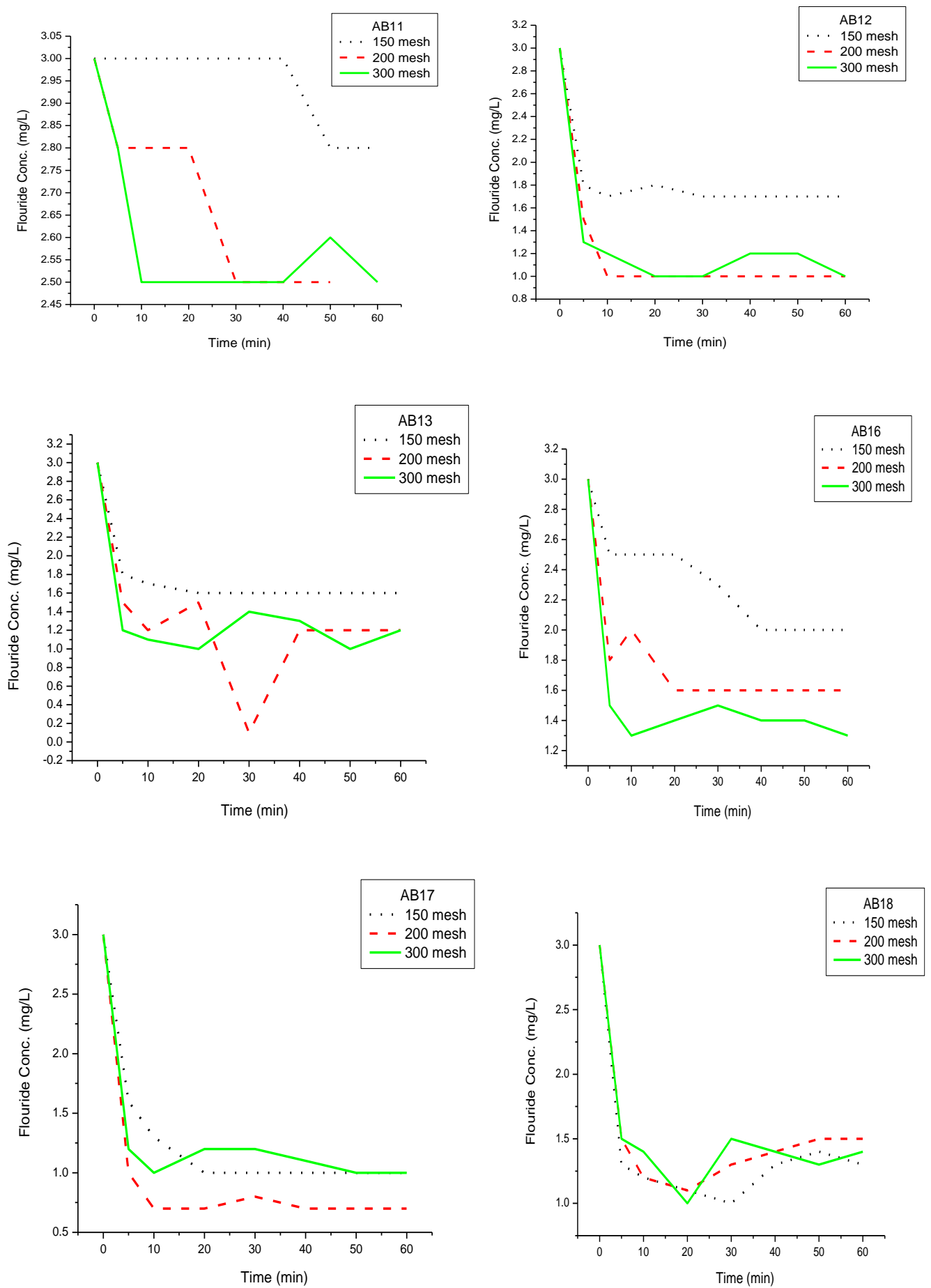

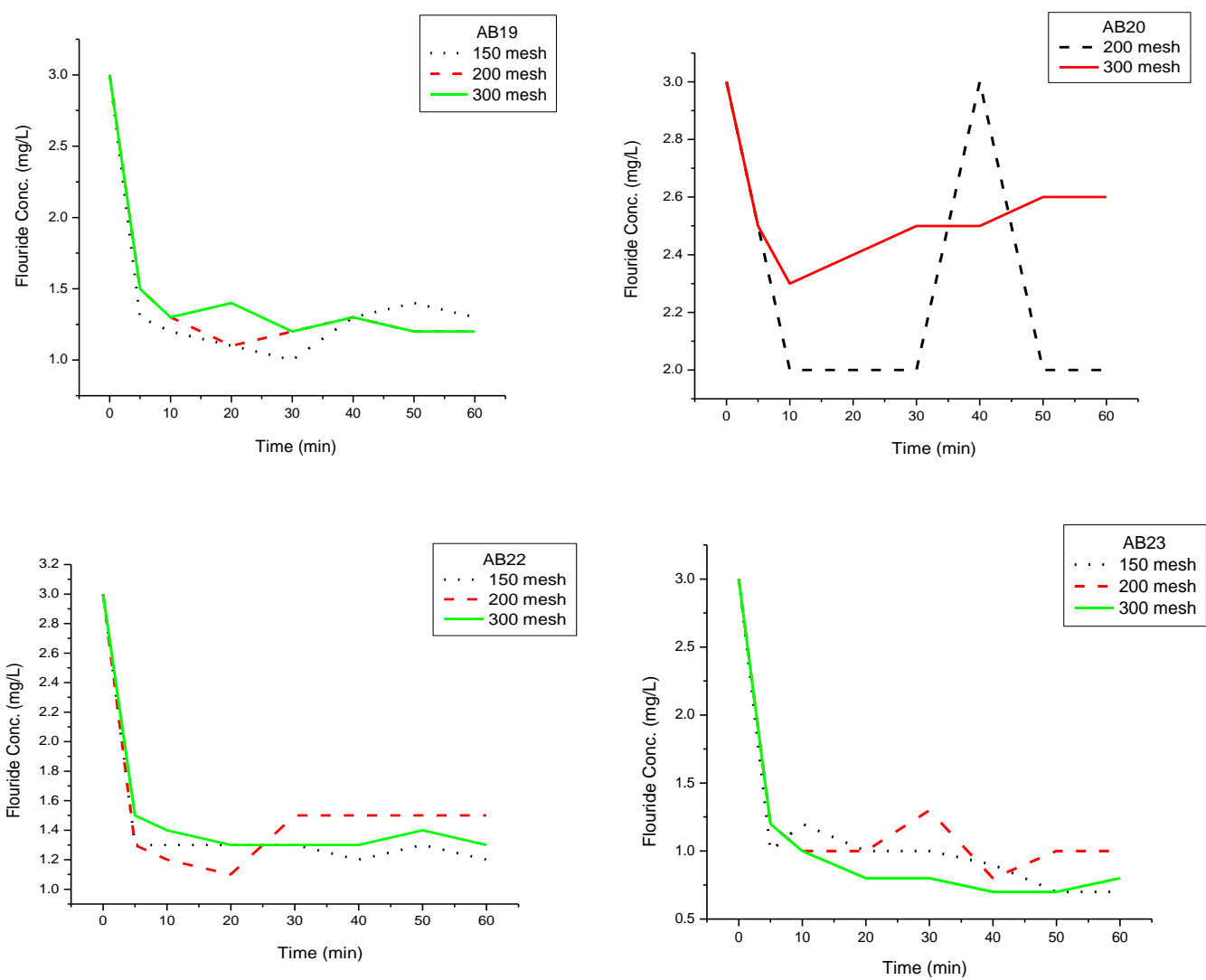

Fig1. Fluoride removal using Jharkhand bentonite
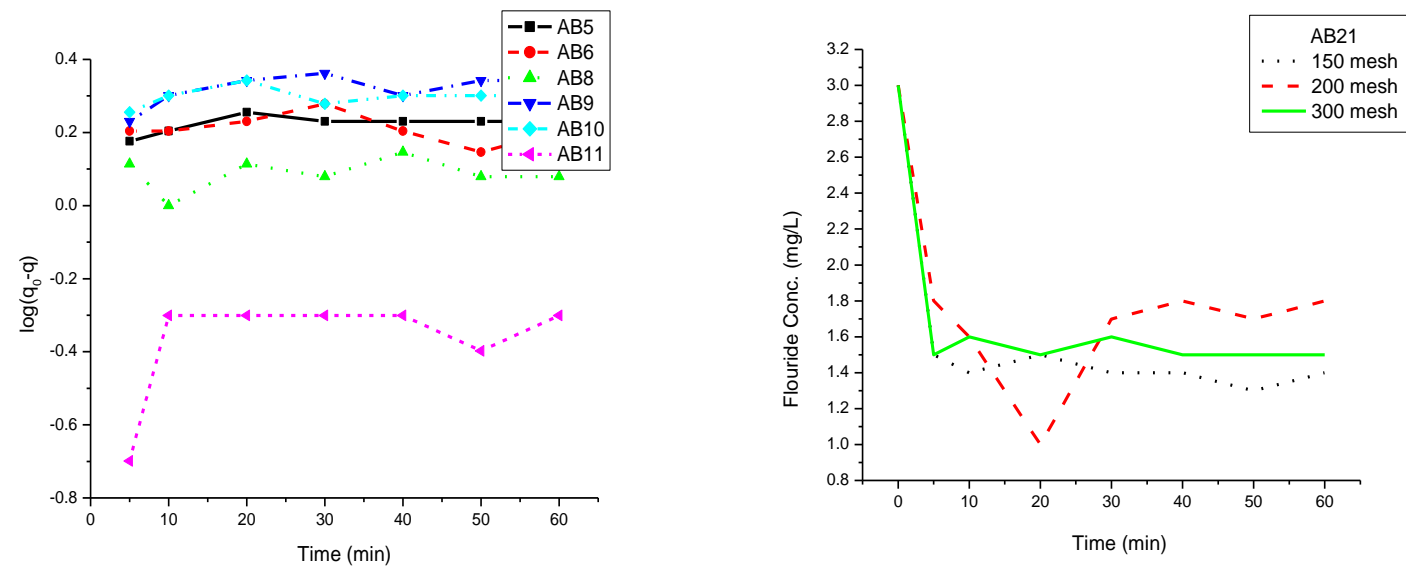

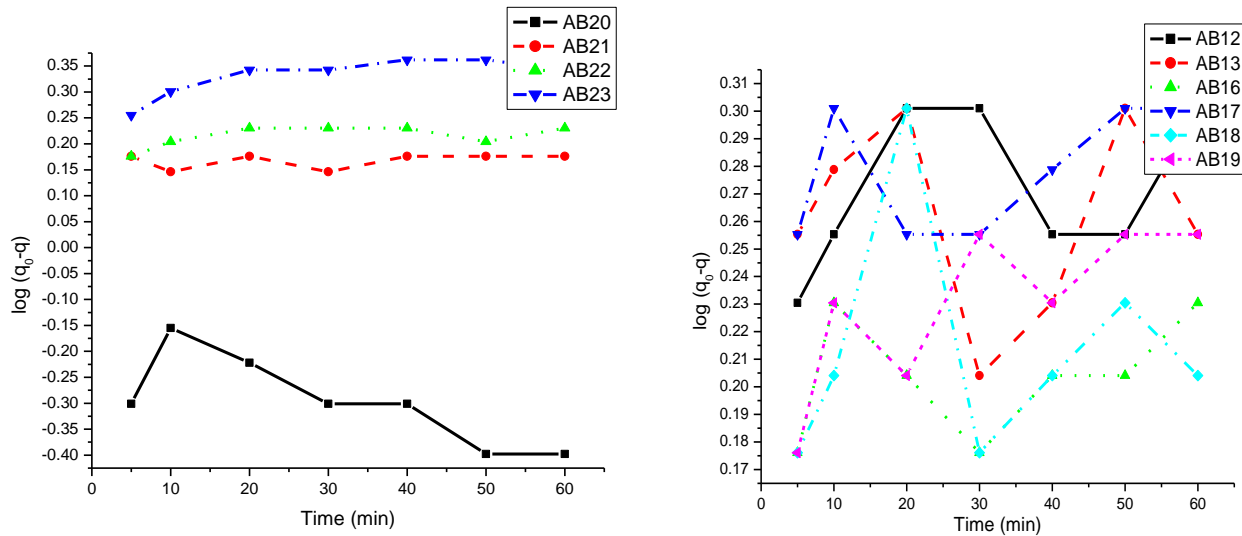

Fig 2. Plot for Kinetics of Fluoride removal using Bentonite (300 Mesh)
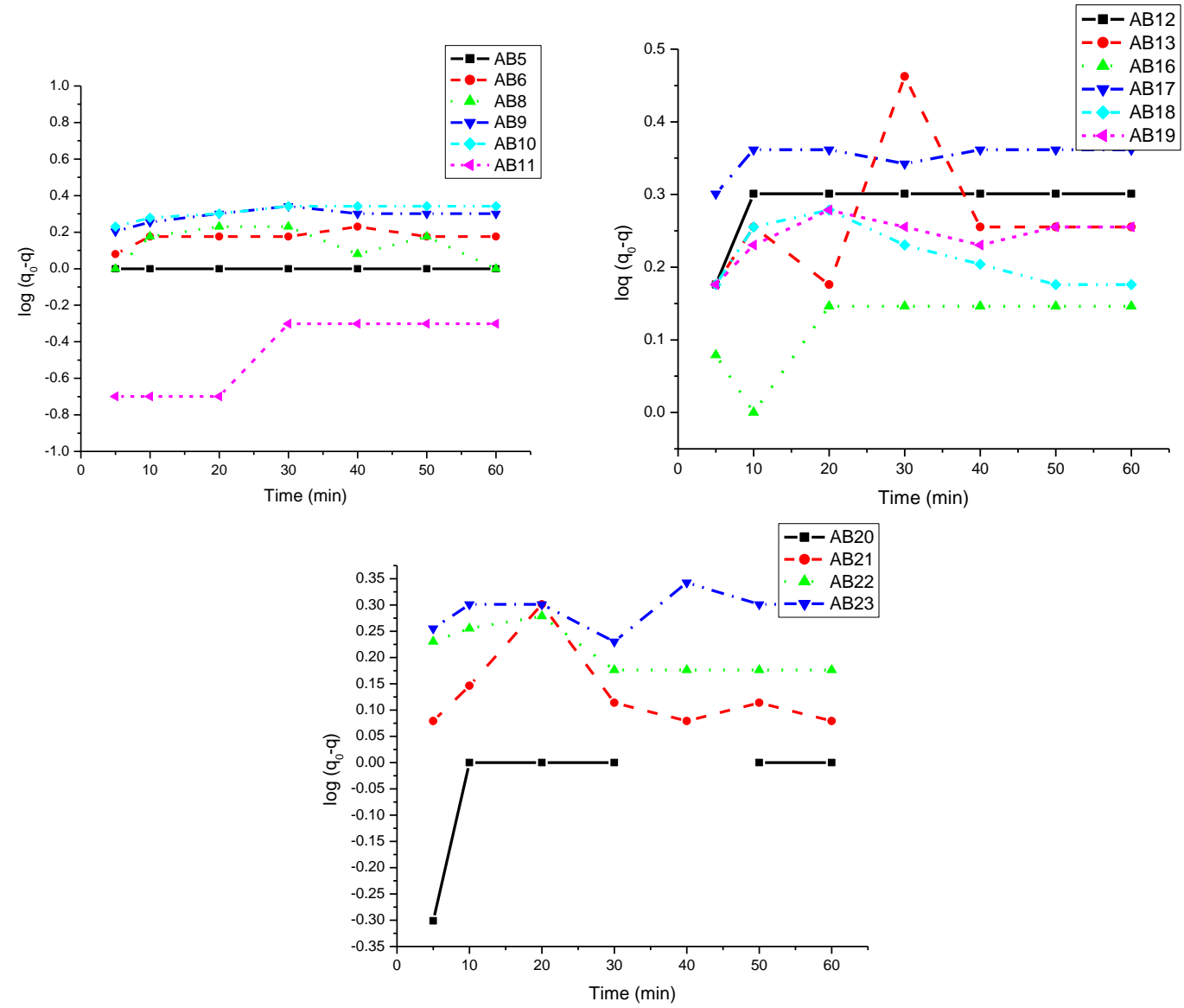

Fig 3.Plot for Kinetics of Fluoride removal usingBentonite (200 Mesh) 

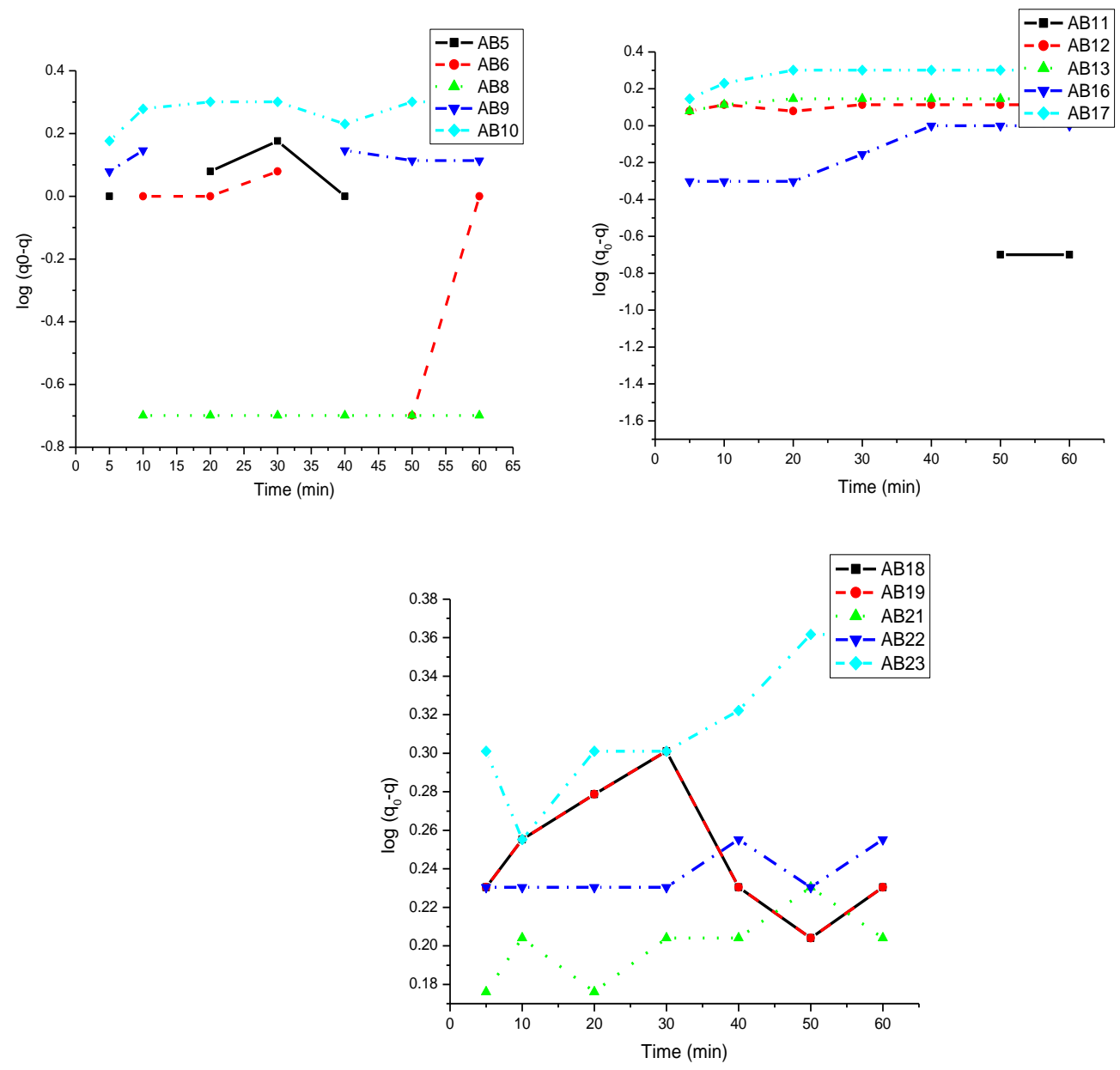

Fig 4.Plot for Kinetics of Fluoride removal usingBentonite (150 Mesh) 